Acta Crystallographica Section D

Biological Crystallography

ISSN 0907-4449

\section{Crystallization and preliminary $X$-ray analysis of human rhinovirus serotype 2 (HRV2)}

\begin{abstract}
Núria Verdaguer, ${ }^{\text {a }}$ Thomas $\mathrm{C}$. Marlovits, ${ }^{\text {b }}$ Jerónimo Bravo, ${ }^{c}$ David I. Stuart, ${ }^{c}$ Dieter Blaas ${ }^{b}$ and Ignacio Fita ${ }^{a_{*}}$
\end{abstract}

${ }^{a}$ Centre d'Investigació i Desenvolupament (CSIC), Jordi Girona 18-26, 08034 Barcelona, Spain, ${ }^{\mathbf{b}}$ Institute of Biochemistry, University of Vienna, Dr. Bohr Gasse 9/3, A-1030 Vienna, Austria, and 'Laboratory of Molecular Biophysics, University of Oxford, South Parks Road, Oxford OX1 3QU, England

+ Present address: Max-Plank-Institute for Biophysics, Department of Structural Biology, Heinrich-Hoffman Strasse 7, D-60528 Frankfurt am Main, Germany.

Correspondence e-mail: ifrcri@cid.csic.es

\begin{abstract}
Human rhinoviruses, the major cause of mild recurrent infections of the upper respiratory tract, are small icosahedral particles. Over 100 different serotypes have been identified. The majority (91 serotypes) use intercellular adhesion molecule 1 as the cell-attachment site; ten serotypes (the minor group) bind to members of the low-density lipoprotein receptor. Three different crystal forms of the minor-group human rhinovirus serotype 2 (HRV2) were obtained by the hangingdrop vapour-diffusion technique using ammonium sulfate and sodium/potassium phosphate as precipitants. Monoclinic crystals, space group $P 2_{1}$, diffracted at least to $2.8 \AA$ resolution, and two complete virus particles were located in the crystal asymmetric unit. A second type of crystals had a compact cubic like morphology and diffracted beyond $2.5 \AA$ resolution. These crystals belong to a primitive orthorhombic space group, with unit-cell parameters $a=309.3, b=353.5, c=759.6 \AA$, and contain one virus particle in the asymmetric unit. A third type of crystals, with a prismatic shape and belonging to space group I222, was also obtained under similar crystallization conditions. These latter crystals, with unit-cell parameters $a=308.7, b=352.2, c=380.5 \AA$, diffracted to high resolution (beyond $1.8 \AA$ ) and contained 15 protomers per asymmetric unit; this requires that three perpendicular crystal twofold axes coincide with three of the viral particle's dyad axes.
\end{abstract}

\section{Introduction}

About $50 \%$ of all common cold infections are caused by human rhinoviruses (HRVs). 102 different serotypes have been identified to date; this large number allows frequent reinfections of the same individual by different serotypes during the life span. HRVs are small ( $\sim 35 \mathrm{~nm}$ in diameter) icosahedral particles which are composed of 60 copies of the four viral proteins VP1, VP2, VP3 and VP4. The capsid encloses the genomic positive (messenger) sense RNA (for a review, see Rueckert, 1996). The majority of the HRV serotypes (91) use intercellular adhesion molecule 1 (ICAM-1) as the cell-attachment site; the minor group (ten serotypes) bind to members of the low-density lipoprotein (LDL) receptor (Hofer et al., 1994). Only HRV87 appears to gain access to the host cell via an uncharacterized glycoprotein (Uncapher et al., 1991). Determination of the three-dimensional structures of three major-group viruses (HRV3, Zhao et al., 1996; HRV14, Rossmann et al., 1985; HRV16, Oliveira et al., 1993) and one minor-group virus (HRV1A, Kim et al., 1989) by X-ray crystallography revealed a high degree of similarity between the various serotypes, regardless of their belonging to the major or to the minor receptor group; only the antigenic epitopes differ substantially.

Recently, the structure of the two N-terminal domains of human ICAM-1 was solved (Bella et al., 1998; Casasnovas et al., 1998). In combination with the low-resolution structure of a complex between HRV16 and soluble recombinant ICAM-1 (Olson et al., 1993), a model was constructed which allowed a tentative identification of amino-acid residues on the viral surface involved in contacts with ICAM-1. These amino acids turned out to be highly conserved within HRVs, even including the minor receptor group virus HRV1A (Bella et al., 1998). Clues as to why minor-group viruses do not use ICAM-1 as the viral receptor might be obtained from comparison of the structures available so far with that of HRV2, another minor receptor group HRV.

Monoclonal antibodies neutralize HRVs by viral aggregation, inhibition of cell attachment or of release of the genomic RNA into the cytosol, or by combinations of these. Complexes between HRV14 (Smith et al., 1995; Smith, Olson, Cheng, Chase et al., 1993; Smith, Olson, Cheng, Liu et al., 1993) or HRV2 (Hewat \& Blaas, 1996; Hewat et al., 1998) with monoclonal antibodies neutralizing the respective serotypes have been solved to low
C) 1999 International Union of Crystallography Printed in Denmark - all rights reserved 
Table 1

HRV2 crystal parameters.

\begin{tabular}{lllll}
\hline Space group & $\begin{array}{l}\text { Resolution } \\
(\AA)\end{array}$ & $\begin{array}{l}\text { Unit-cell parameters } \\
\left(\AA,{ }^{\circ}\right)\end{array}$ & $\begin{array}{l}\text { Virions } \\
\text { per cell }\end{array}$ & $\begin{array}{l}\text { Packing density } \\
\left(\AA^{3} \mathrm{Da}^{-1}\right)\end{array}$ \\
\hline$P 2_{1}$ & 2.8 & $\begin{array}{c}a=469.3, b=381.8, \\
c=472.4 ; \beta\end{array}$ & 4 & 2.8 \\
$\begin{array}{l}\text { Primitive } \\
\text { orthorhombic }\end{array}$ & 2.5 & $\begin{array}{c}a=309.3, b=353.6 \\
c=759.6\end{array}$ & 4 & 2.8 \\
$\begin{array}{l}a=308.7, b=352.2, \\
c=380.5\end{array}$ & 2 & 2.8 \\
\hline
\end{tabular}

$\dagger$ Calculated assuming a relative mass per virion of $7.5 \times 10^{6} \mathrm{Da}$. resolution by electron cryo-microscopy. However, important structural details required for efficient neutralization can only be seen at high resolution. This either requires crystallization of the complex (Smith et al., 1996) or extension of the resolution by combining electron micronents (i.e. from virus and from antibody or receptor; Bella et al., 1998). The structure of at least one of the HRV2-neutralizing antibodies is available at atomic resolution (Tormo et al., 1992, 1994) and a model of the viral complex was built using the data of HRV1A. However, although closely related to HRV2, this serotype has substantially different neutralizing immunogens (Tormo et al., 1995), which prevents reliable predictions of the antibody-virus interface.

For the reasons given above, we felt it highly desirable to solve the structure of HRV2, an extensively characterized minorgroup rhinovirus. In the current paper, we report the crystallization of HRV2 and the arrangement of the viral particles within the unit cell.

\section{Experimental}

HRV2, originally obtained from Dr D. Tyrrell, Common Cold Centre, Salisbury, England, was routinely grown in Rhino HeLa cells (Flow Laboratories) maintained in 11 suspension cultures at $307 \mathrm{~K}$ (Skern et al., 1984). About $40 \mathrm{~h}$ post-infection, at a scopy data with X-ray data of the compo- multiplicity of infection of $\sim 1$, cells and cell debris were collected by low-speed centrifugation, cells were broken with a Dounce homogenizer and the virus was collected by differential centrifugation. Virus pellets from a 41 tissue culture were suspended in $1 \mathrm{ml} 20 \mathrm{~m} M$ Tris- $\mathrm{HCl}$ (pH 7.5), $2 \mathrm{~m} M \mathrm{MgCl}_{2}$ (virus buffer) and digested with RNAase I and DNAase (Boehringer Mannheim) at a final concentration of $0.25 \mathrm{mg} \mathrm{m}^{-1}$ for $10 \mathrm{~min}$ at room temperature. Trypsin (GIBCO) was then added to $0.3 \mathrm{mg} \mathrm{ml}^{-1}$ and incubation was continued for $5 \mathrm{~min}$ at $310 \mathrm{~K}$. The solution was adjusted to $1 \%$ $N$-laurylsarcosine and left overnight at $277 \mathrm{~K}$. Insoluble material was removed at $14000 \mathrm{rev} \mathrm{min}^{-1}$ for $15 \mathrm{~min}$ in an Eppendorf centrifuge. The virus in the supernatant was laid on top of a $7-45 \%$ sucrose density gradient prepared in virus buffer and centrifuged in a SW28 Beckman rotor at $25000 \mathrm{rev} \mathrm{min}^{-1}$ for $3.5 \mathrm{~h}$. The virus was detected as an opalescent band in the middle of the gradient and was collected by puncturing the tube with a needle. After dilution with buffer, HRV2 was pelleted by highspeed centrifugation and resuspended in $300 \mu \mathrm{l} 50 \mathrm{~m} M$ Tris-HCl (pH 7.4). The quality of different viral preparations was judged by denaturing polyacrylamide gel electrophoresis and conventional negative-staining transmission electron microscopy. For crystallization, only preparations containing more than $95 \%$ native virions, as seen from the absence of stain inside the particles, were used.

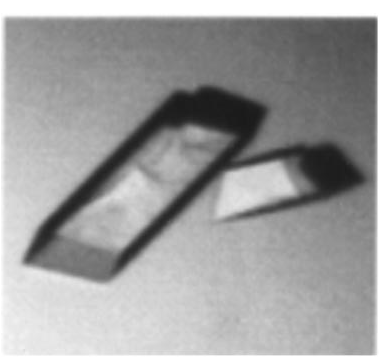

(a)

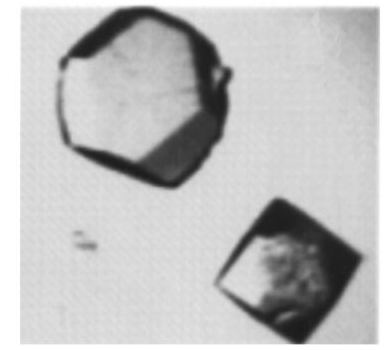

(b)

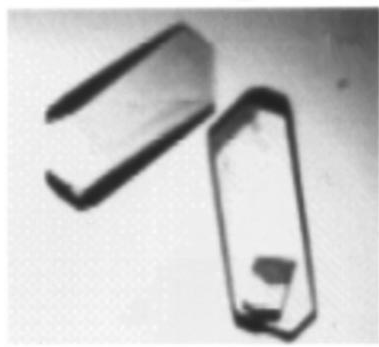

(c)
Figure 1

Photomicrographs of the HRV2 crystals: $(a)$ monoclinic $P 2_{1},(b)$ primitive orthorhombic and $(c)$ body-centred orthorhombic $I 222$.
HRV2 crystallized in three different crystal morphologies (Fig. 1) using the hanging-drop vapour-diffusion method. Typically, $2-5 \mu \mathrm{l}$ of virus solution $\left(5 \mathrm{mg} \mathrm{ml}^{-1}\right)$ in $50 \mathrm{~m} M$ Tris- $\mathrm{HCl}$ (pH 7.4) was mixed with an equal or smaller volume of reservoir solution. Parallelepiped-shaped crystals (Fig. 1a), growing to approximately $0.6 \times 0.2 \times 0.15 \mathrm{~mm}$ in size, were obtained at 0.9-1.0 $M$ ammonium sulfate and $0.1 M$ sodium/potassium phosphate at $\mathrm{pH}$ 7.0. These crystals appeared within $3-5 \mathrm{~d}$ at room temperature and diffracted at least to $2.8 \AA$ resolution using synchrotron radiation. Partial data sets were collected at the Science and Engineering Research Council's Synchrotron Radiation Source (SRS) facility at Daresbury, Cheshire, England. Data collection was performed at beamline station 9.6 at a wavelength of $0.88 \AA$ using ADSC Quantum 4 CCD and MAR 345 detectors. Crystals belong to the monoclinic space group $P 2_{1}$, and packing considerations indicated that they could contain two virions in the asymmetric unit yielding 120-fold noncrystallographic symmetry (Table 1). A second crystal form with a cubic like morphology (Fig. $1 b$ ) was obtained at room temperature at $\mathrm{pH} 7.5 \mathrm{using} 0.2 \mathrm{M}$ ammonium sulfate and $0.1 \mathrm{M}$ sodium/potassium phosphate as precipitants. Crystals appeared within a month, reaching sizes of $0.3 \times 0.3 \times$ $0.15 \mathrm{~mm}$. A similar crystal morphology also grew at $277 \mathrm{~K}$ in $2-3 \%$ PEG 8000 and $0.1 \mathrm{M}$ sodium/potassium phosphate at $\mathrm{pH}$ 7.5. These crystals diffracted at least to $2.5 \AA$ resolution using synchrotron radiation (beamline X11 at DESY, Hamburg), but were stable in the X-ray beam for only 1-2 exposures. The unit cell, characterized using $0.3^{\circ}$ rotation diffraction images analyzed with the MOSFLM package (Leslie, 1992), was consistent with a primitive orthorhombic space group (Table 1). From the unit-cell dimensions, one virus particle is expected to be found per asymmetric unit (60-fold non-crystallographic symmetry). A third type of crystals with prismatic morphology and dimensions up to $0.3 \times 0.2$ $\times 0.15 \mathrm{~mm}$ was also obtained at room temperature and $\mathrm{pH} \quad 7.5$ using $0.4 \mathrm{M}$ ammonium sulfate and $0.1 \mathrm{M}$ sodium/ potassium phosphate (Fig. 1c). These crystals, with unit-cell parameters $a=308.7$, $b=352.2, c=380.5 \AA$, diffracted to high resolution (beyond $1.8 \AA$ ); however, they were extremely sensitive to X-ray radiation. A data set at $2.5 \AA$ resolution was collected from 65 crystals mounted in sealed capillary tubes using synchrotron radiation $(\lambda=0.96 \AA$ at beamline X11 at DESY, Hamburg). Data was evaluated using the MOSFLM (Leslie, 
Table 2

Data evaluation statistics from the $I 222$ crystals at $2.5 \AA$ resolution.

\begin{tabular}{ll}
\hline Number of crystals used & 65 \\
Number of images & 180 \\
Total number of reflections & 459326 \\
Number of independent reflections & 286695 \\
Completeness $(\%)$ & 60 \\
Average $I / \sigma(I)$ & 3.9 \\
$R_{\text {merge }}$ & 10.8 \\
\hline
\end{tabular}

1992) and DENZO (Otwinowski \& Minor, 1996) packages (Table 2). The crystals belong to the orthorhombic space group I222 (Table 1) and contain two virions per unit cell (15 protomers per asymmetric unit), which requires that three perpendicular crystal twofold axes coincide with three of the viral particle's dyad axes. Therefore, the centres of the two virion particles in the unit cell had to be located at $(0,0,0)$ and $\left(\frac{1}{2}, \frac{1}{2}, \frac{1}{2}\right)$, with the particles oriented in one of only two possible orientations. These two alternative orientations are related by a $90^{\circ}$ rotation around any of the three coincident twofold axes. Structure determination was performed using molecular replacement with the $X$-PLOR (Brünger, 1992) and DM (Cowtan, 1994) programs, using as starting models the coordinates of the minor-group rhinovirus HRV1A in the two possible orientations. The initial $R$ factors calculated for the two search models were 50.0 and $36.0 \%$, respectively, for data to $3.5 \AA$ resolution, thus providing an unambiguous discrimination, clearer than the self-rotation function, between the two alternative orientations. Structure refinement on this $I 222$ crystal form is now in progress.

This work was supported by grants PB950218 of DGICYT to IF and P12269-MOB from the Austrian Science Foundation to DB. Data collection at the synchrotron was supported by the Human Capital and Mobility Program of the European Union.

\section{References}

Bella, J., Kolatkar, P. R., Marlor, C. W., Greve, J. M \& Rossmann, M. G. (1998). Proc. Natl Acad. Sci. USA, 95, 4140-4145.

Brünger, A. T. (1992). X-PLOR Manual. Yale University, New Haven, Connecticut, USA.

Casasnovas, J. M., Stehle, T., Liu, J. H., Wang, J. H. \& Springer, T. A. (1998). Proc. Natl Acad. Sci. USA, 95, 4134-4139.

Cowtan, K. (1994). Jnt CCP4/ESF-EACBM Newslett. Protein Crystallogr. 31, 34-38.

Hewat, E. A. \& Blaas, D. (1996). EMBO J. 15, 1515-1523.

Hewat, E. A., Marlovits, T. C. \& Blaas, D. (1998). J. Virol. 72, 4396-4402.

Hofer, F., Gruenberger, M., Kowalski, H., Machat, H., Huettinger, M., Kuechler, E. \& Blaas, D. (1994). Proc. Natl Acad. Sci. USA, 91, 18391842.

Kim, S., Smith, T. J., Chapman, M. S., Rossmann, M. G., Pevear, D. C., Dutko, F. J., Felock, P. J., Diana, G. D. \& McKinlay, M. A. (1989). J. Mol. Biol. 210, 91-111.

Leslie, A. G. W. (1992). Jnt CCP4 ESF/EACMB Newslett. Protein Crystallogr. 26.

Oliveira, M. A., Zhao, R., Lee, W. M., Kremer, M. J., Minor, I., Rueckert, R. R., Diana, G. D. Pevear, D. C., Dutko, F. J., McKinlay, M. A. \& Rossmann, M. G. (1993). Structure, 1, 51-68.
Olson, N. H., Kolatkar, P. R., Oliveira, M. A., Cheng, R. H., Greve, J. M., McClelland, A., Baker, T. S. \& Rossmann, M. G. (1993). Proc. Natl Acad. Sci. USA, 90, 507-511.

Otwinowski, Z. \& Minor, W. (1996). Methods Enzymol. 276, 307-326.

Rossmann, M. G., Arnold, E., Erickson, J. W., Frankenberger, E. A., Griffith, J. P., Hecht, H.-J., Johnson, J. E., Kamer, G., Luo, M., Mosser, A. G., Rueckert, R. R., Sherry, B. \& Vriend, G. (1985). Nature (London), 317, 145153.

Rueckert, R. R. (1996). Virology, edited by B. N. Fields \& D. M. Knipe, pp. 609-654. New York: Raven Press.

Skern, T., Sommergruber, W., Blaas, D., Pieler, C. \& Kuechler, E. (1984). Virology, 136, 125-132.

Smith, T. J., Chase, E. S., Schmidt, T. J., Olson, N. H. \& Baker, T. S. (1996). Nature (London), 383, 350-354.

Smith, T. J., Mosser, A. G. \& Baker, T. S. (1995). Semin. Virol. 6, 233-242.

Smith, T. J., Olson, N. H., Cheng, R. H., Chase, E. S. \& Baker, T. S. (1993). Proc. Natl Acad. Sci. USA, 90, 7015-7018.

Smith, T. J., Olson, N. H., Cheng, R. H., Liu, H., Chase, E. S., Lee, W. M., Leippe, D. M., Mosser, A. G., Rueckert, R. R. \& Baker, T. S. (1993). J. Virol. 67, 1148-1158.

Tormo, J., Blaas, D., Parry, N. R., Rowlands, D., Stuart, D. \& Fita, I. (1994). EMBO J. 13, 22472256.

Tormo, J., Centeno, N. B., Fontana, E., Bubendorfer, T., Fita, I. \& Blaas, D. (1995). Proteins Struct. Funct. Genet. 23, 491-501.

Tormo, J., Stadler, E., Skern, T., Auer, H., Kanzler, O., Betzel, C., Blaas, D. \& Fita, I. (1992). Protein Sci. 1, 1154-1161.

Uncapher, C. R., Dewitt, C. M. \& Colonno, R. J. (1991). Virology, 180, 814-817.

Zhao, R., Pevear, D. C., Kremer, M. J., Giranda, V. L., Kofron, J. A., Kuhn, R. J. \& Rossmann, M. G. (1996). Structure, 4, 1205-1220. 